\title{
Performance of Agriculture sector in India with Special Reference to Food grains
}

\author{
Mukesh Kumar*, Dr. Shallu Sehgal** \\ *Research Scholar, Department of Economics, University of Jammu, Jammu. \\ **Assistant Professor in Economics, Department of Economics, University of Jammu, Jammu.
}

\begin{abstract}
In the present study, an attempt has been made to know the performance of agriculture sector in India by knowing the trends in area, production and productivity of food grain crops in India for the period 1980-81 to 2012-13. It has been observed that the compound growth rate in the area under total food grain revealed a declining trend. The production of total food grain crops grow at the rate of 1.94 per cent per annum during the study period. The productivity of total food grains grow at a rate of 2.08 per cent per annum. The overall average production of total food grains is 188.37 million tonnes out of which Rice has maximum average production i.e. 78.68 million tonnes during the study period. The overall average productivity of total food grain is $1522.06 \mathrm{~kg} / \mathrm{hectare}$ out of wheat has maximum average productivity i.e. $2440.70 \mathrm{~kg} / \mathrm{hectare}$. The overall average area under total food grains is registered 125.93 million hectare out of which Rice has occupied maximum average area i.e. 42.48 million hectare. But, the overall absolute variability (Standard Deviation) in the production of total food grain is registered 35.39 million tonnes which is about 18.79 per cent (Coefficient of Variation). Similarly, the overall absolute change (Standard Deviation) in the productivity of total food grain is $279.29 \mathrm{~kg} / \mathrm{hectare}$ which is 19.53 per cent (Coefficient of Variation) and the overall change in the area under cultivation of food grain crops is only 3.28 million hectares which is about 2.65 per cent during the study period.
\end{abstract}

Keywords: Cultivation, Production, Variability, Crop.

\section{Introduction}

This study aims at investigating variations and trends in the production, area and productivity in Indian agriculture from 1980-81 to 2012-13. Indian economy has undergone a structural change over time with the anticipated decline in the share of agriculture in the GDP. There is fall in its share from 55.1 percent in 1950-51 to 17 percent in 2008-09. Due to this decline in the share, the importance of agriculture has not diminished because the country achieved self-sufficiency in the food production at the macro level, but still is a food deficit country facing massive challenges of high prevalence of mal nourished children and high incidence of rural poverty (Sundaram.et al, 2011). But India has made an impressive progress in agricultural front during the past three decades. Much of the credit for this success should go to the several million small farming families that form the backbone of Indian agriculture and Indian economy. Policy support, production strategies, public investment in infrastructure, research and extension for crops, livestock and fisheries have significantly helped in increasing the agricultural productivity, food production and its availability (Kumar.et.al, 2006). This paper accesses the trends and variability in area, production and yield of food grains in Indian agriculture.

\section{Objectives:}

1. To study the trend and growth of area, production and Productivity of Food grain in India.

2.To analyze the production and productivity status of food grains in India.

\section{Scope of the study:}

The scope of the study is confined to whole India where production and productivity trends for major food grain cropswere selected for the study i.e. 1980-81 to 2012-13.

\section{Sources of Data:}

The present analysis was based on secondary source data relating to the production and productivity of major food crops. The data was obtained from various secondary sources such as RBI Data Base, Ministry of Agriculture, Government of India, New Delhi etc.

\section{Methodology:}

For the purpose of the analysis, the entire study period is split into three sub periods including Period I: 1980-81 to 1989-90; Period II: 1990-91 to 1999-00; Period-III: 2000-01 to 2012-13 and the Overall Period: 
1980-81 to 2012-13 and accordingly Compound growth rates, Means, Standard Deviations and Co-efficient of Deviations of area, production and productivity of selected food grain crops in the three periods were estimated to examine the fluctuations.

\section{Results and Explanation}

India is the second largest producer of food in the world. At present India produces more than 200 million tonnes of Food Grains, 150 million tonnes of fruits and vegetables, 91 million tonnes of milk, 1.6 million tonnes of poultry meat, 417 million livestock, and 6.05 million tonnes of fish and fish products. The Indian agriculture has made great strides over the years. The Food Grain production has increased more than fourfold from 51 million tonnes in 1950-51 to 212 million tonnes during 2003-04 growing at an annual average rate of more than 2.4 per cent per annum. The recent trends in performance of Indian agricultural production, however, present a dismal picture (Murthy.et.al. 2014). The estimated compound growth rate of Food Grains with respect to production, productivity and area of three periods, i.e. Period-I (1980-81 to 1989-90), Period-II (1990-91 to 1999-00), Period-III (2000-01 to 2012-13) and one Overall period from 1980-81 to 2012-13 have been presented in the following table.

\section{Compound Growth Rate in the Production, Productivity and Area of Food Grains. \\ 1.1. Compound Growth Rate of Production}

The production of major Food Grains in the past few decades has been characterized by fluctuations with low growth. Performance throughout the 1980s (Period-I) was low with cereal production increasing at a rate of 0.35 per cent per annum, followed by Pulses, 1.49 per cent, Wheat, 3.58 per cent and Rice3.62 per cent per annum(Table 1).

Table: 1

Compound Growth in Production, Productivity and Area of Food Grains in India

\begin{tabular}{|c|c|c|c|c|}
\hline & PERIOD-I & PERIOD-II & PERIOD-III & OVERALL \\
\hline & & RICE & & \\
\hline AREA & 0.41 & 0.67 & -0.09 & 0.27 \\
\hline PRODUCTION & 3.62 & 2.02 & 1.90 & 2.03 \\
\hline \multirow[t]{2}{*}{ PRODUCTIVITY } & 3.19 & 1.34 & 1.95 & 1.75 \\
\hline & & WHEAT & & \\
\hline AREA & 0.46 & 1.72 & 1.34 & 0.82 \\
\hline PRODUCTION & 3.58 & 3.57 & 2.74 & 2.60 \\
\hline \multirow[t]{2}{*}{ PRODUCTIVITY } & 3.10 & 1.82 & 1.30 & 1.75 \\
\hline & & COARSE CEREALS & & \\
\hline AREA & -1.34 & -2.11 & -1.19 & -1.55 \\
\hline PRODUCTION & 0.35 & -0.01 & 2.73 & 0.96 \\
\hline \multirow[t]{2}{*}{ PRODUCTIVITY } & 1.71 & 2.14 & 3.91 & 2.54 \\
\hline & & TOTAL CEREALS & & \\
\hline AREA & -0.26 & 0.04 & 0.00 & -0.19 \\
\hline PRODUCTION & 2.85 & 2.20 & 2.36 & 2.01 \\
\hline \multirow[t]{2}{*}{ PRODUCTIVITY } & 3.10 & 2.16 & 2.31 & 2.20 \\
\hline & & PULSES & & \\
\hline AREA & -0.10 & -0.60 & 1.50 & 0.07 \\
\hline PRODUCTION & 1.49 & 0.86 & 3.65 & 0.97 \\
\hline \multirow[t]{2}{*}{ PRODUCTIVITY } & 1.59 & 1.27 & 0.57 & 0.48 \\
\hline & & $\begin{array}{ll}\text { TOTAL } & \text { FOOD } \\
\text { GRAINS } & \\
\end{array}$ & & \\
\hline AREA & -0.23 & -0.08 & 0.25 & -0.15 \\
\hline PRODUCTION & 2.73 & 2.10 & 2.44 & 1.94 \\
\hline PRODUCTIVITY & 2.97 & 2.17 & 2.14 & 2.08 \\
\hline
\end{tabular}

Source: Computed on the basis of data available at RBI data base.

In the pre reform period (before 1991), the prices of most of the Food Grain items were higher in the international market in comparison to domestic market that made Indian to produce more and more Food Grain before economic reforms to the advantage of the higher prices. But when the world agricultural market liberalized under WTO commitments, the supply of Food Grains increased in the international market. However, demand did not increase due to the inelastic demand of Food Grains and consequently international prices declined and become less than the domestic market and farmers lost their zest for more and more production of Food Grains(Yadav, 2005). 
Figure: 1

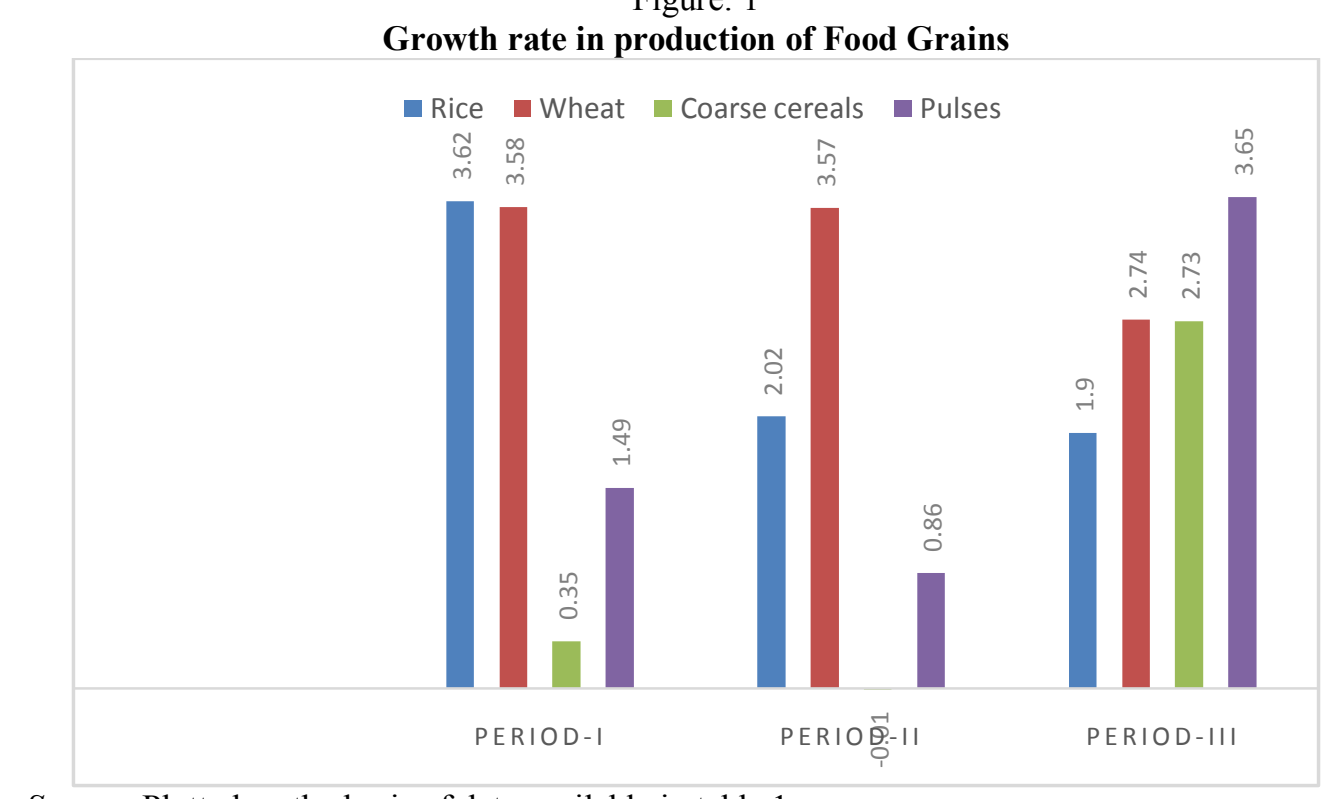

Source: Plotted on the basis of data available in table 1.

In Period-II compound growth rate estimated 3.57 per cent in Wheat production and 2.02 per cent in Rice production. The growth rate in theproduction of Wheat and Rice during the Period-II and III have declined because there is a comparatively higher requirement of fertilizers, high Productivity varieties of seeds, proper irrigation facilities etc. in comparison to the production of Pulses and Coarse Cereals. Since the cost of all the items has increased over the reform period, it becomes unaffordable for farmers to purchase the appropriate doses of all the inputs and as a result the growth of production of Wheat and Rice decelerated in the reform period. The unusual behavior of monsoon in the post reform period has also adversely affected the production of Wheat and Rice as both the items require a good amount of irrigation.But Pulses and Coarse Cereals are completely different from Rice and Wheat, which require not only a comparatively lower amount of fertilizer, but also a lesser irrigation facilities and therefore it has not been much affected by rising prices of fertilizers and unusual behavior of monsoon in the reform period but by a decline in the area of these crops (Ahmed et.al. 2012). In case of cereals there is negative growth registered in coarse cereal production during the Period-II, but Total Cereals grow at 2.20 per cent per annum. There is also showing a declining trend in the production of Pulses during the 1990s, which was declined from 1.49 per cent in 1980 s to 0.86 per cent during 1990s. The main reason for declining the production of Pulses is that there is declining in the area under Pulses sharply from 1990s till date. The growth pattern of Pulses is decreased sharply during the Period-II, which shows that during the Period-II farmers have shown lesser interest towards the production of Pulses in that period in comparison to Period-I. But during the Period-III the growth rate increased to 3.65 per cent per annum (Ahmed. et. al. 2012). The secondary data has revealed that the trend is same in the SAARC countries too. This is also the major cause of continuous rise in the prices of Pulses in India (Kumar. et. al. 2012). During the Period-III the average annual production of Pulses increases to 3.65 per cent per annum because of an increase in the area under Pulses production from -0.60 per cent to 1.50 per cent in the Period-III. Total Food Grain production declined from 2.73 per cent during 80 s to 2.10 per cent during the 90 s which is due to declining in the cropped area under Total Food Grains. But during the Period-III growth rate of production was at 2.44 per cent per annum because there is also increased in the area under Total Food Grains i.e. from -0.08 per cent to 0.25 per cent. The overall average production of Food Grains is 1.94 per cent per annum, which is lesser than the decadal growth because there is a decline in the overall area under Food Grain production to -0.15 per cent per annum. Growth rate of Total Food Grain production during Period-II has declined because before the introduction of New Economic Policy agricultural inputs were highly subsidized and available at lower prices than it may be in a free market. But after 1999, the cost of fertilizers, seeds, irrigation facilities, etc. has increased and it became difficult for the small farmers to purchase it and consequently Total Food Grain production declined (Ahmed. et. al. 2012).

\subsection{Compound Growth Rate of productivity.}

In India Policy support, production strategies, public investment in infrastructure, research and extension in crop, livestock and fisheries have significantly helped in increasing the agricultural productivity, food production and its availability (Kumar \& Mittal, 2006). The analysis of data shows that during Period-I there is a 3.19 per cent increase in the productivity of Rice, which is further declined to 1.34 per cent because of 
a decline in the production of Rice. But during the Period-III productivity of Rice increases to 1.95 per cent per annum, which is due to increase in the production of Rice during the same period.

Figure: 2

Growth rate in productivity of Food Grains

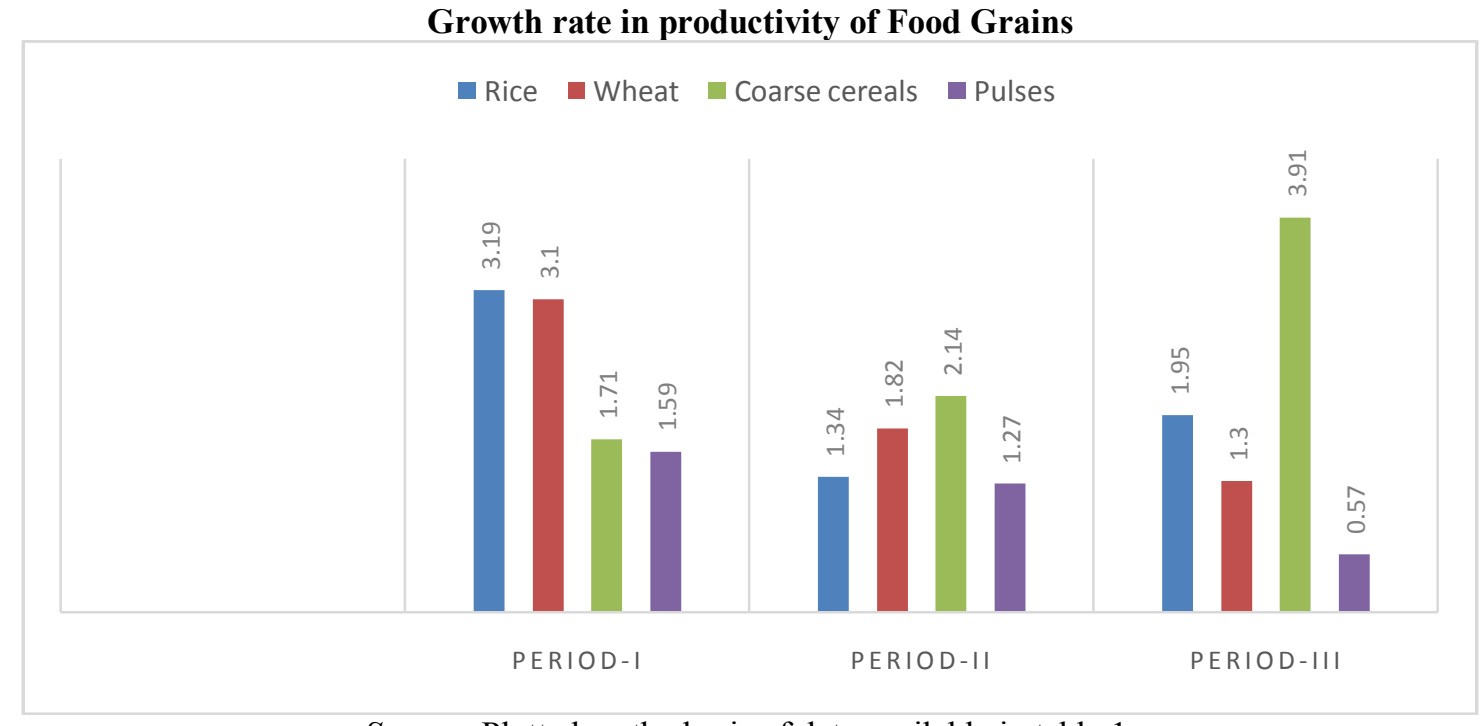

Source: Plotted on the basis of data available in table 1.

On the other hand, the share of total factor productivity (TFP) in the growth rate of Rice and Wheat production is declining. The Productivity growth is more input based. The use of modern inputs (e.g., HighYield varieties, irrigation, chemical fertilizers, and pesticides) in the IGP (Indo-Gangetic Plain) has already been achieved with a high level. The organic sources of nutrients (such as organic manure and legumes area) are rapidly declining in the RWCS (Rice-Wheat Cropping System). Further scope of increasing Productivity of Rice and Wheat from modern inputs and area expansion seems to be remote. Better management of existing soil and water resources can enhance the growth in Productivity and production of the RWCS (Kumar. et. al. 2000). The productivity of Wheat during 1980s is 3.10 per cent, which declined to 1.82 per cent during the $90 \mathrm{~s}$ and further 1.30 per cent during 2000s. Coarse Cereals showing an increasing trend in the productivity growth, but the productivity of Total Cereals decrease during the Period-II. Pulses on the other hand also registered declining trend in per hectare productivity due to decrease in the area under production of Pulses. The per hectare productivity of Total Food Grain is 2.97 per cent in 80 s declined to 2.17 per cent during the $90 \mathrm{~s}$ and further 2.14 per cent during 2000s. Decline in the productivity of the Total Food Grains is due to decline in the productivity of Wheat, Rice, Pulses and Total Cereals.

\subsection{Compound Growth Rate of Area.}

It is clear from the available information that the growth rate of the area under cultivation for the production of Food Grains has grown very slowly in the pre reform period or even negative growth registered in the post reform period does not mean that all the policies of the government to increase the area under cultivation have failed. This might have happened because as the process of industrialization and urbanization accelerated more and more agricultural land brought under non- agricultural uses. The problem of soil erosion also negatively affected the growth of the cultivable land. We should say thanks to the Indian government who stresses more on bringing uncultivable land under cultivation with the help of different land development programmes like water Programme (Ahmed et.al. 2012).

Agriculture in India today is constrained by various factors. We have created history by producing 259 million Tonnes of Food Grains in 2012-13, but this has been accompanied by land degradation, declining size of land holdings and many other related problems (RBI Data Base).

The cropping pattern in India has undergone significant changes over time. As the cultivated area remains more or less constant, the increased demand for food because of the increase in population and urbanization puts agricultural land under stress resulting in crop intensification and substitution of food crops with commercial crops (Kannan, 2011). 
Figure: 3

Growth rate in area of Food Grains

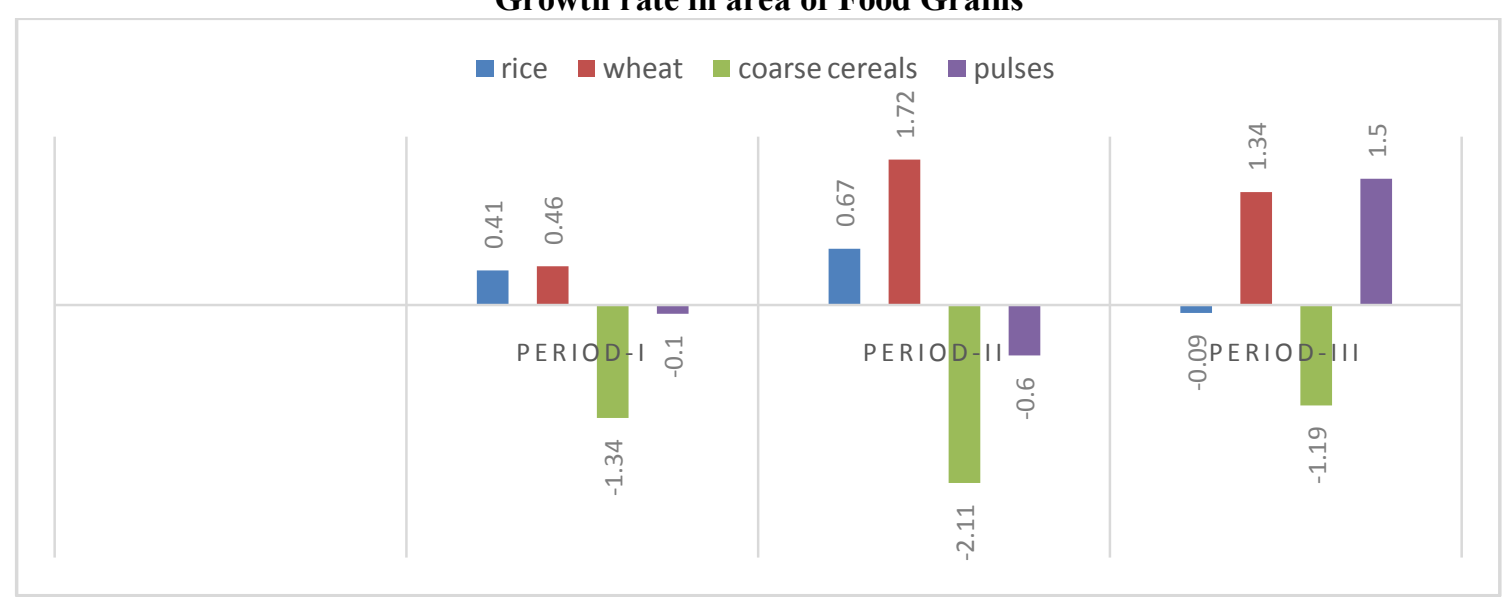

Source: Plotted on the basis of data available in table 1

In fact, it is striking to observe that the overall area under Total Food Grains declined by -0.15 per cent, mainly due to fall in an area under Coarse Cereals by -1.55 per cent between 1980-81 and 2012-13 (Table 4.1). A study by Kumar et al (2012) revealed that area under Food Grains has contracted during the nineties. Wheat has gained importance with area allocation of only 1.72 per cent in Period-II, and it is almost constant at 1.34 per cent in the Period-III. Area under Rice remained more or less constant during the period under study. Interestingly, the area lost by Food Grains was used for the cultivation of oilseeds, fruits, vegetables and nonfood crops. Although the shift from Coarse Cereals to high value crops is likely to increase farm output and income to farmers, in dry land regions it will expose cultivators to serious weather- borne risks because high value crops have a high water requirement (Kannan, 2011). There has also increased in area under total Pulses from -0.60 per cent in Period-II to 1.50 per cent during the Period-III and the overall area under Pulses is 0.07 per cent per annum between 1980-81 and 2012-13. The area under Coarse Cereals came down from -1.34 per cent during 1980s to -2.11 per cent during 1990 s and further -1.19 per cent during the Period-III.

After the introduction of Green Revolution, method of production of Wheat completely changed. Now for the production of Wheat there is required of high Productivity varieties of seeds, high doses of fertilizers and finely irrigation facilities that cannot be done without the help of assuring irrigation facilities. All these activities are costly affairs and therefore as the New Economic Policy implemented, there is a many fold rise in the prices of these products and consequently deceleration in the growth of the area under cultivation is observed (Ahmed et.al. 2012).

\subsection{Average production of Food Grains}

\section{Average Production, Productivity and Area under food grains.}

During 2011-12, there was a record production of Food Grains at 259.32 million tonnes, of which 131.27 million tonnes during Kharif season and 128.05 million tonnes during the Rabi season (RBI Data Base). Average production of the selected Food Grains has been exhibited in table 4.2. A perusal of the table shows that the overall average production of Rice between 1980-81 and 2012-13 is 78.68 million tonnes. There found an increasing trend in the production of all Food Grains during the study period. There is a sharp increase in the average production of Rice from 59.78 million tonnes in Period-I to 80.10 million tonnes in Period-II and 92.12 million tonnes in the Period-III. Similarly the average production of Wheat also increased from 44.76 million tonnes in Period-I to 63.91 million tonnes in Period-II and 77.57 million tonnes in the Period-III. In case of Coarse Cereals average production increased from 29.86 million tonnes in Period-I to 31.12 million tonnes in Period-II and 36.11 million tonnes in the Period-III. However, production of Rice and Wheat plays an important role in increasing the average production of Total Cereals from 134.39 million tonnes in Period-I to 175.13 million tonnes in Period-II and 205.80 million tonnes in the Period-III. The average production of the Total Food Grains observed as 146.55 million tonnes in Period-I, 188.64 million tonnes in Period-II and 220.34 million tonnes in the Period-III. The overall average production of Rice is highest (78.68Mt) which is followed by Wheat (63.49Mt), Coarse Cereals (32.70) and Pulses (13.51Mt). 
Table: 2

\section{Average Production of different Food Grains in India}

(In Million Tonnes)
\begin{tabular}{|l|l|l|l|l|}
\hline CROPS & PERIOD-I & PERIOD-II & PERIOD-III & OVERALL \\
\hline RICE & 59.78 & 80.10 & 92.12 & 78.68 \\
\hline WHEAT & 44.76 & 63.91 & 77.57 & 63.49 \\
\hline COARSE CEREALS & 29.86 & 31.12 & 36.11 & 32.70 \\
\hline TOTAL CEREALS & 134.39 & 175.13 & 205.80 & 174.87 \\
\hline PULSES & 12.16 & 13.51 & 14.54 & 13.51 \\
\hline TOTAL FOOD GRAINS & 146.55 & 188.64 & 220.34 & 188.37 \\
\hline
\end{tabular}

Source: Computed on the basis of data available at RBI data base.

Figure: 4

Average production of Food Grains

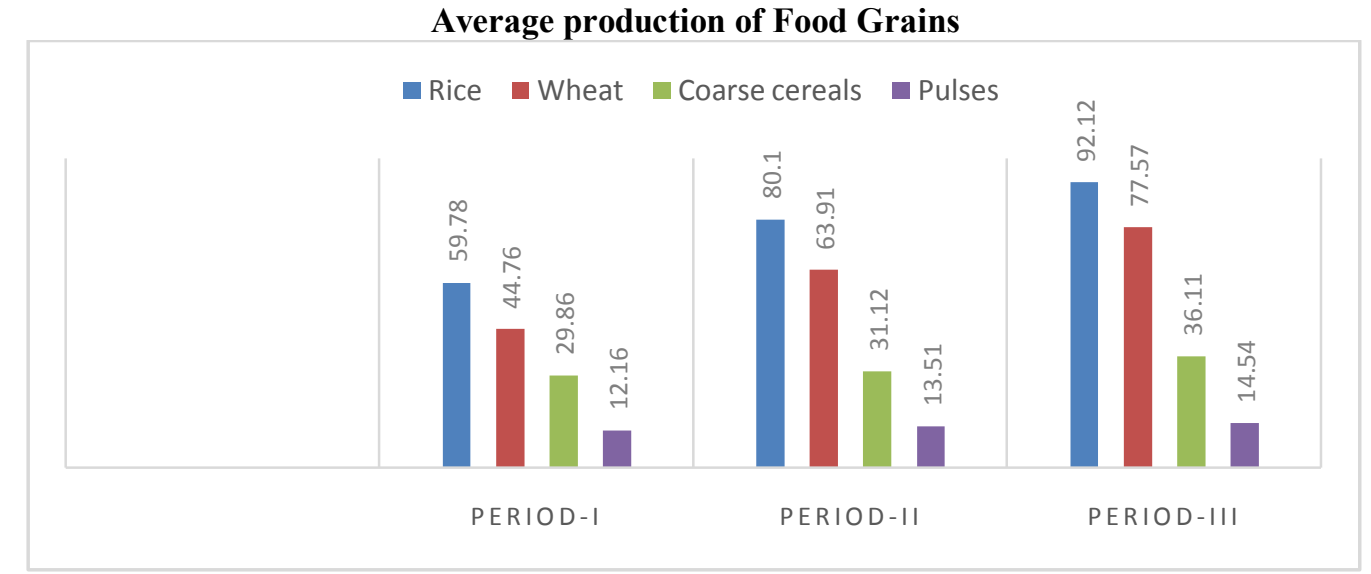

Source: Plotted on the basis of data available in table 2.

The analysis reveals that the entire increase in Food Grain output during 1980s is therefore the result of the rise in productivity per hectare, as a result of the increase in Productivity-raising inputs. There was a significant increase in the productivity of all inputs combined or total factor productivity (TFP) (Rao and Gulati, 1994).

\subsection{Average productivity of Food Grains.}

Due to lack of irrigation facilities, agricultural production largely depends upon timely rainfall and weather conditions. Within agriculture, Food Grain production is by far the major activity and providing the main staple source of food in the country. Food Grains provide almost all the calories and proteins consumed by the poor and give the rural people with the bulk of their employment. So the growth of agriculture sector depends on production and productivity of Food Grains.

Table: 3

Average Productivity of different Food Grains in India

\begin{tabular}{|l|l|l|l|l|}
\hline CROPS & PERIOD-I & PERIOD-II & PERIOD-III & OVERALL \\
\hline RICE & 1467.10 & 1852.00 & 2052.80 & 1842.21 \\
\hline WHEAT & 1917.90 & 2495.60 & 2721.10 & 2440.70 \\
\hline COARSE CEREALS & 751.70 & 970.90 & 1196.40 & 1028.39 \\
\hline TOTAL CEREALS & 1295.80 & 1735.30 & 1986.70 & 1735.49 \\
\hline PULSES & 526.40 & 591.50 & 562.50 & 574.94 \\
\hline TOTAL FOOD GRAINS & 1155.70 & 1525.40 & 1731.20 & 1522.06 \\
\hline
\end{tabular}

Source: Computed on the basis of data available at RBI data base.

The average productivity of selected Food Grain crops is presented in table 4.3. The average productivity of Rice is $1842.21 \mathrm{~kg} /$ hectare between $1980-81$ and $2012-13$. The average productivity of Rice during $1980 \mathrm{~s}$ was $1467.10 \mathrm{~kg} /$ hectare, increased to $1852 \mathrm{~kg} /$ hectare during $1990 \mathrm{~s}$ and $2052.80 \mathrm{~kg} / \mathrm{hectare}$ during 2000s. 
Figure: 5

Average productivity of Food Grains

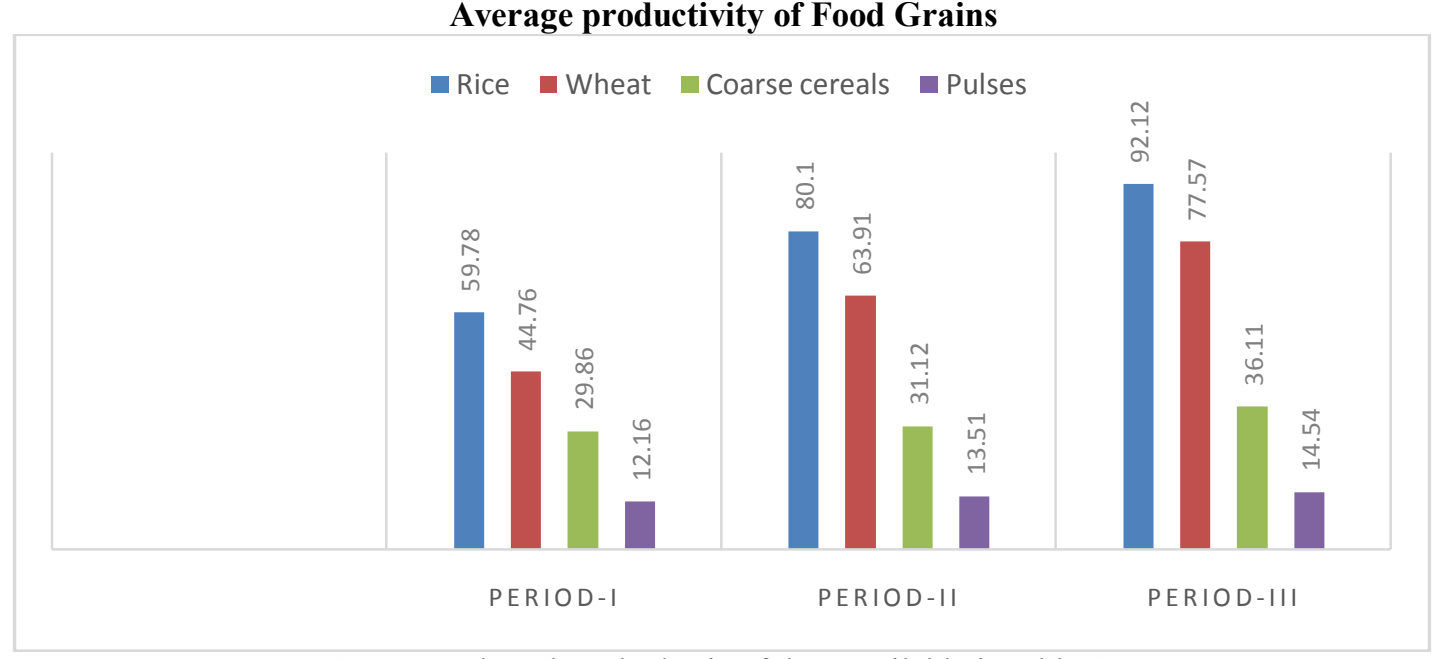

Source: Plotted on the basis of data available in table 3.

The above table shows that among the Food Grains all the Food Grains showing their increasing trend. Per hectare Wheat production recorded maximum $(2440.70 \mathrm{~kg} /$ hectare $)$ among all the selected crops under Food Grains, which is followed by Rice $1842.21 \mathrm{~kg} / \mathrm{h}$, Coarse Cereals $1028.39 \mathrm{~kg} / \mathrm{h}$ and Pulses $574.94 \mathrm{~kg} / \mathrm{h}$. The maximum Productivity per hectare is recorded in Wheat during the Period-III.

\subsection{Average Area under Food Grains.}

Average area under major Food Grains is shown in table 4. The overall average area under Rice was estimated to be 42.48 million hectares which was maximum than others. During Period-I (1980-81 to 1989-90), area under this crop was about 40.65 million hectares increased to 43.22 million hectares in Period-II and 43.31 million hectare in Period-III. There are various reasons for the increase in the area under Rice during the PeriodII and III.

Table: 4

Average Area under Different Food Grains in India

(In Million Hectares)
\begin{tabular}{|l|l|l|l|l|}
\hline CROPS & PERIOD-I & PERIOD-II & PERIOD-III & OVERALL \\
\hline RICE & 40.65 & 43.22 & 43.31 & 42.48 \\
\hline WHEAT & 23.30 & 25.55 & 27.51 & 25.64 \\
\hline COARSE CEREALS & 39.77 & 32.14 & 28.19 & 32.89 \\
\hline TOTAL CEREALS & 103.73 & 100.90 & 99.03 & 101.02 \\
\hline PULSES & 23.08 & 22.71 & 23.06 & 22.96 \\
\hline TOTAL FOOD GRAINS & 126.81 & 123.60 & 121.96 & 123.93 \\
\hline
\end{tabular}

Source: Computed on the basis of data available at RBI data base.

Firstly, whatever there has been growth in the area under cultivation all is utilized towards the production of Rice in the post-reform period or since lesser choice is available for the production of the crops in that area. Secondly, the introduction of the New Economic Policy increases the prices of fertilizers and therefore it seems suitable to produce Rice in place of Wheat or other crops where comparatively better huge doses of fertilizers are required. Thirdly, comparatively better prices for Rice is in comparison to Wheat in the international market may be a reason behind growing Rice in a year in the states like Punjab and West Bengal (Ahmed et.al. 2012).

The table 4 further revealed that the average area under Wheat was nearly 23.30 million hectares which increases to 25.55 million hectares in the Period-II and further 27.51 million hectares in the Period-III. The overall average area under Wheat, estimated about 25.64 million hectares. The average area under Coarse Cereals is about 39.77 million hectares in Period-I which further declined to 32.14 million hectares and 28.19 million hectares in Period-II and Period-III. 
Figure: 6

Average area under Food Grains

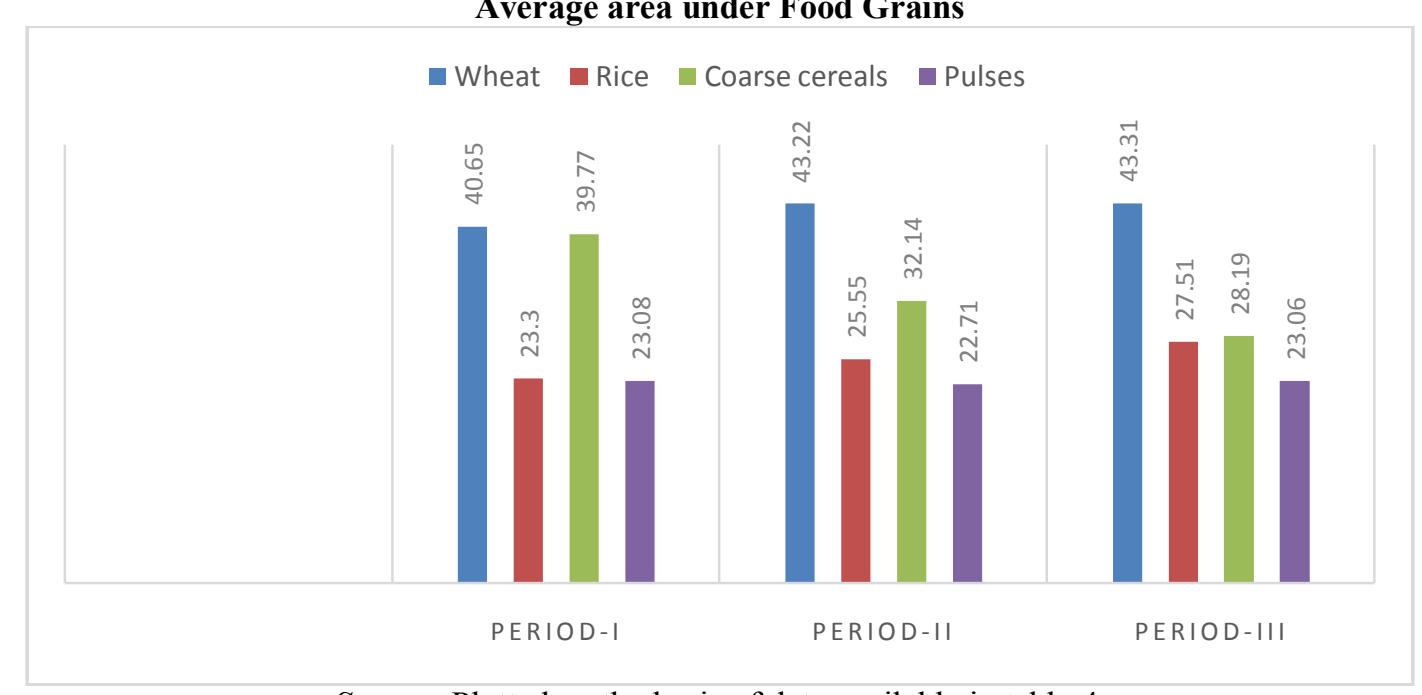

Source: Plotted on the basis of data available in table 4 .

The overall average area under Coarse Cereals was about 32.89 million hectares. In case of Total Cereals, the overall average area under Total Cereals was nearly 101.02 million hectares which was 103.73 million hectares in Period-I followed by 100.90 million hectares in Period-II and 99.03 million hectare in Period-III. In case of Pulses the average area under Pulses is about 23.08 million hectares which is almost equal to the Period-III (23.06 million hectares). The overall average area under Pulses is near about 22.96 million hectares which is almost same in Period-II (22.71 million hectares). Moreover, there is the highest average area under Total Food Grain is in Period-I (126.81 million hectare) which was further decreased to 123.96 million hectares and 121.96 million hectare in Period-III. The overall average area under cultivation for Total Food Grains from 1980-81 to 2012-13 was nearly 123.93 million hectares. However, the ever increasing growth was observed in Rice and Wheat during the study period. But in case of Coarse Cereals, area decreased from higher level to lower level. It is striking to observe that the area under Food Grains has declined over the study period. This was mainly due to the decrease in Coarse Cereals area from 39.77 million hectares during 1980s to 32.14 million hectares in 1990s and further 28.19 million hectares during 2000s. Percentage area under different crop exhibits changes over time. Crops that are more remunerative often replace less remunerative ones. As a result less remunerative crops are pushed to claim less fertile land and this process leads to an increase in the total area under cultivation. Pressure of population further accelerates this process (Mishra S.K).

\section{Standard Deviation and Coefficient of Variation in Production, Productivity and Area.}

3.1. Standard Deviation and Coefficient of Variation in Production.

To find out variability in production, productivity and area two statistical methods are used, i.e. the Standard Deviation which gives an absolute measure of variability and Coefficient of Variations which indicates the Percentage Change in the Variability. The entire period of study is split into three parts and one overall period from $1980-81$ to $2012-13$.

Table: 5

Standard Deviation and Coefficient of Variation of Production of different Food Grains in India

\begin{tabular}{|c|c|c|c|c|c|c|c|c|}
\hline \multirow[t]{2}{*}{ CROPS } & \multicolumn{2}{|c|}{ PERIOD-I } & \multicolumn{2}{|c|}{ PERIOD-II } & \multicolumn{2}{|c|}{ PERIOD-III } & \multicolumn{2}{|c|}{ OVERALL } \\
\hline & SD & $\mathrm{CV}$ & SD & $\mathrm{CV}$ & SD & $\mathrm{CV}$ & SD & $\mathrm{CV}$ \\
\hline RICE & 7.57 & 12.67 & 5.14 & 6.42 & 8.68 & 9.42 & 15.33 & 19.49 \\
\hline WHEAT & 5.01 & 11.18 & 6.77 & 10.59 & 8.92 & 11.49 & 15.40 & 24.26 \\
\hline COARSE CEREALS & 2.94 & 9.83 & 2.74 & 8.79 & 4.80 & 13.28 & 4.66 & 14.25 \\
\hline TOTAL CEREALS & 13.34 & 9.92 & 11.92 & 6.80 & 21.19 & 10.30 & 33.87 & 19.37 \\
\hline PULSES & 0.99 & 8.16 & 0.87 & 6.46 & 2.22 & 15.28 & 1.86 & 13.74 \\
\hline $\begin{array}{l}\text { TOTAL } \\
\text { GRAINS }\end{array}$ & 14.13 & 9.64 & 12.44 & 6.59 & 23.22 & 10.54 & 35.39 & 18.79 \\
\hline
\end{tabular}

S.D. $=$ Standard Deviation (Million Tonnes)

C.V. = Coefficient of Variation (In Per cent)

Source: Computed on the basis of data available at RBI data base. 
The analysis of variability in production of Food Grains is presented in table no.4.5. The table reveals that the overall change in terms of quantity recorded to be high in Wheat production (15.40 million tonnes) followed by Rice (15.33), Coarse Cereals (4.66) and the minimum in Pulses (1.86). The period wise analysis further indicates that the maximum change in Food Grains is in the production of Wheat (8.92) during the Period-III and minimum (5.01) in Period-I. In case of Rice maximum production is in a Period-III (8.68) and minimum in Period-II (5.14). The same trend is also seen in Coarse Cereals and Pulses. While in case of Total Cereals maximum variability was recorded in the Period-III and minimum in Period-II. In case of the Total Food Grains maximum variability was observed in the Period-III and minimum in Period-II.

In terms of percentage, the maximum overall percentage change in Food Grain is in the production of Wheat (24.26 per cent) followed by Rice (19.49 per cent), Coarse Cereals (14.25 per cent) and Pulses (13.74 per cent) respectively. In case of Total Cereals there is a 19.37 per cent change in production between 1980-81 and 2012-13 and in case of the Total Food Grains there is a 18.79 per cent change in production between 1980-81 and 2012-13. The period wise analysis further indicates that in case of Rice the maximum variability was recorded during Period-I and minimum in Period-II. But in case of Wheat maximum percentage change was recorded in the Period-III and minimum during Period-II. The similar trend was found in Coarse Cereals and Pulses. While in case of Total Cereals maximum change was found during the Period-III and minimum in Period-II. Total Food Grains also showing the maximum change in Period-III and minimum in Period-II. The reason for the maximum percentage change in Period-III is due to maximum change in production of Food Grains in absolute terms.

\subsection{Standard Deviation and Coefficient of Variation in Productivity.}

The food production and increase in productivity are essential for meeting the growing demands for food in the future. There is widespread opinion that this growing demand can be met by increased use of inputs or increase in agricultural productivity. Productivity growth of agriculture in India over the past four decades was the result of a combination of factors such as new incentives to farmers offered by the government who considered them as autonomous economic agents, and physical factors such as land, labour, capital (in the form of machines, working animals, irrigation system, and so on), and intermediate inputs such as fertilizer (Tripathy, 2008). Change in the productivity of selected crops is presented in table no 4.6.

Table: 6

Standard Deviation and Coefficient of Variation of Productivity of different Food Grains in India

\begin{tabular}{|l|l|l|l|l|l|l|l|l|}
\hline \multirow{2}{*}{ CROPS } & \multicolumn{2}{|l}{ PERIOD-I } & \multicolumn{2}{l|}{ PERIOD-II } & \multicolumn{2}{l|}{ PERIOD-III } & \multicolumn{2}{l|}{ OVERLL } \\
\cline { 2 - 9 } & SD & CV & SD & CV & SD & CV & SD & CV \\
\hline RICE & 153.15 & 10.44 & 82.54 & 4.46 & 132.98 & 6.48 & 309.16 & 16.78 \\
\hline WHEAT & 179.93 & 9.38 & 149.92 & 6.01 & 87.13 & 3.20 & 403.41 & 16.53 \\
\hline COARSE CEREALS & 78.13 & 10.39 & 88.49 & 9.11 & 146.29 & 12.23 & 267.41 & 26.00 \\
\hline TOTAL CEREALS & 126.39 & 9.57 & 111.31 & 6.41 & 125.74 & 6.33 & 357.37 & 20.59 \\
\hline PULSES FOOD & 34.45 & 6.54 & 34.76 & 5.88 & 117.90 & 20.96 & 89.19 & 15.51 \\
\hline $\begin{array}{l}\text { TOTAL } \\
\text { GRAINS }\end{array}$ & 108.21 & 9.36 & 99.68 & 6.53 & 104.60 & 6.04 & 279.29 & 19.53 \\
\hline
\end{tabular}

S.D. $=$ Standard Deviation $(\mathrm{Kg} . /$ Hectare $)$

C.V. $=$ Coefficient of Variation (In Per cent)

Source: Computed on the basis of data available at RBI data base.

The analysis of change in the productivity of Food Grains is presented in table no.4.6. This table reveals that the overall change in terms of quantity per hectare was recorded to be high in Wheat followed by Rice, Coarse Cereals and minimum in Pulses. Change in kilograms per hectare of Total Cereals (357.37 $\mathrm{kg} /$ hectare) is much more than a change in kilograms per hectare of Total Food Grains. The period wise analysis further indicates that in case of Rice, the maximum change was found in Period-I $(153.15 \mathrm{~kg} / \mathrm{h})$ and minimum in Period-II $(82.54 \mathrm{~kg} / \mathrm{h})$. In case of Wheat maximum variability was found in Period-I $(179.93 \mathrm{~kg} / \mathrm{h})$ and minimum in the Period-III $(87.13 \mathrm{~kg} / \mathrm{h})$. But in case of Coarse Cereals and Pulses, it is reverse, i.e. the maximum variability was found in Period-III and minimum was in Period-I. In case of Total Cereals maximum variability was found in Period-I and minimum was in Period-II which is due to that maximum change of Rice was found during Period-I and minimum during Period-II. The same trend was also seen in Total Food Grains. In terms of percentage, the overall maximum variability was observed in case of Coarse Cereals (26 per cent) followed by Rice (16.78 per cent), Wheat (16.53 per cent) and Pulses (15.51 per cent), respectively. The period wise analysis indicates that in case of Rice the maximum variability was found in Period-I and minimum was in Period-II. In case of Wheat maximum variability was found in Period-I and minimum was in a Period-III. The similar trend was found in Total Cereals as well as Total Food Grains. In case of both Coarse Cereals and Pulses maximum variability was found in Period-III and minimum was in Period-II. 


\subsection{Standard Deviation and Coefficient of Variation in Area.}

It is evident from the table no. 4.7 that the period wise analysis, among Food Grains showing a fluctuation in the variability in the area both in absolute terms and in percentage. The overall variability in terms of area was recorded to be high in Coarse Cereals (5.15 million hectares) followed by Wheat (2.14 million hectares), Rice (1.68 million hectares) and Pulses (1.27 million hectares). The period wise analysis further indicates that in case of Rice the maximum change in area in million hectares was found in Period-III and minimum was in Period-II. In case of Wheat maximum change in area in million hectares was found in PeriodIII but minimum in Period-I. The same trend was also seen in Pulses. In case of Coarse Cereals maximum variability was found in Period-II and minimum was in a Period-III. In case of Total Cereals maximum change was found in Period-I and minimum was in Period-II. Total Food Grains show that maximum change was registered in the Period-III and minimum was in Period-II.

In terms of percentage, the overall maximum variability was observed in case of Coarse Cereals followed by Wheat, Pulses and Rice. The period wise analysis further indicates that in case of Rice maximum percentage change in area was observed in the Period-III and minimum was in Period-II. The same trend was found in the area of Total Cereals and Total Food Grains. In case of Wheat maximum variability was found in Period-III and minimum was in Period-I. The same trend was found in Pulses.

\section{Table: 7}

Standard Deviation and Coefficient of Variation of Area of different Food Grains in India

\begin{tabular}{|l|l|l|l|l|l|l|l|l|}
\hline \multirow{2}{*}{ CROPS } & \multicolumn{2}{|l|}{ PERIOD-1 } & \multicolumn{2}{l|}{ PERIOD-2 } & \multicolumn{2}{l|}{ OVERALL } \\
\cline { 2 - 9 } & SD & CV & SD & CV & SD & CV & SD & CV \\
\hline RICE & 1.18 & 2.90 & 0.99 & 2.29 & 1.27 & 2.94 & 1.68 & 3.94 \\
\hline WHEAT & 0.73 & 3.12 & 1.33 & 5.20 & 1.46 & 5.30 & 2.14 & 8.34 \\
\hline COARSE CEREALS & 1.78 & 4.48 & 2.09 & 6.52 & 1.60 & 5.68 & 5.15 & 15.66 \\
\hline POTAL CEREALS & 2.22 & 2.14 & 1.20 & 1.19 & 2.12 & 2.14 & 2.73 & 2.71 \\
\hline $\begin{array}{l}\text { TOTALSES FOOD } \\
\text { GRAINS }\end{array}$ & 0.81 & 3.50 & 0.88 & 3.86 & 1.70 & 7.38 & 1.27 & 5.51 \\
\hline
\end{tabular}

S.D. = Standard Deviation (Million Hectares).

C.V = Coefficient of Variation (In Per cent).

Source: Computed on the basis of data available at RBI data base.

In fact, it is observed that area under Total Food Grains has declined by 1.77 million hectares due to decline in the area of Rice and Pulses during the Period-II. Total Cereals also declined by 1.20 million hectares due to decline in the area under Rice by 0.99 million hectares during Period-II. Further, there is an increase in the area of Food Grains by 2.89 million hectares which is due to increase in the area of Total Ceresals as well as Pulses by 2.12 million hectares and 1.70 million hectares.

\section{Conclusion}

In short, one can say that the average production and productivity of Food Grain crops are increasing during the study period. But these crops are not growing at an increasing rate as shown in the above table. The growth rate of Rice is 2.03 per cent per annum during the study period. Wheat has registered a growth of 2.60 per cent during the study period. But the growth in the productivity of both the crops is same during the study period. The average production and productivity of both the crops showing an increasing trend during the study period. The growth rate in the production of Rice and Wheat declined during the three periods. Similarly, the overall growth rate of Coarse Cereals is 0.96 per cent and the production of Total Cereals grow at a rate of 2.54 per cent per annum and of Total Cereals at 2.20 per cent per annum during the study period. On the other hand, the overall average production and productivity of Coarse Cereals is only 32.70 million tonnes and 1028.39 $\mathrm{kg} /$ hectare. But the average production and productivity of total cereal is 174.87 million tonnes and 1735.49 $\mathrm{kg} /$ hectare during the study period.

\section{References}

[1]. Ahmed. M.D FirdosandHaseenShaukat, (2012), "The Performance ofIndia's Food Grains Production: A Pre and Post Reform Assessment" International JournalofScientificandResearchPublications, Vol.2,Issue. 3, Published by: International Journal ofScientificandResearch Publications.

[2]. ChaudharyShilpa, (2012), "Trends in total factor productivity in Indian agriculture: State level evidence using Non-Parametric Sequential Malmquist" Centrefordevelopmenteconomics,DepartmentofEconomics,DelhischoolofEconomics, Working paperNo.215. 
[3]. DharSoma, (2013), "Trend and Performance ofMajor Food Grain Production" AnOnlineJournalofHumanities\&SocialScience,Publishedby:Department of Bengali KarimganjCollege, Karimganj, Assam, India.

[4]. DholakiaRavindrahandDholakia. Bakul.H,(1993),"GrowthofTotalFactor Productivity inIndian Agriculture" IndianEconomicReview,NewSeries Vol.28, No.I,pp.25-40.

[5]. Gadgil SulochanaandGidgilSiddhartha, (2006), "TheIndian Monsoon, GDPandAgriculture" Economic andPoliticalWeekly,Vol. 41, No. 47, pp. 4887+4889-4895,Published by:EconomicandPolitical Weekly.

[6]. JunankarP.N,(1986), "Mobility and Inequality inIndian Agriculture" Economic andPolitical Weekly,Vol.21, No.13,pp.A45-A47.

[7]. KannanElumalai and SundaramSujata, (2011), "Analysis ofTrendsinIndia's Agricultural Growth" TheInstitute for Social andEconomic Change, Bangalore, working paper 276.

[8]. KannanElumalai, (2012), "Trends inIndia's Agricultural Growth andits Determinants" Asian Journal ofAgriculture and Development, Vol.08, No.02,pp.79-99.

[9]. Kumar Pradumanand Mittal Surabhi, (2006), "Agricultural Productivity Trends inIndia: Sustainability Issues"AgriculturalEconomicsResearchReview,Vol.19, pp71-88.

[10]. Kumar PradumanandRosegrantMark, (1994), "Productivity and sources of Growth for Rice in India" Economic andPolitical Weekly,Vol.29, No.53, pp. A183-A188, Published by:EconomicandPolitical Weekly.

[11]. Kumar Sanjay and PrasharDeepak, (2012), "An analysis onchanging trends of FoodGrains in Himachal Pradesh" International journalofpharmacy\&life sciences,Vol.3,No.6,pp. 1739-1742.

[12]. Vaidyanathan. A, (2000), "India's Agricultural Development Policy" Economic andPolitical Weekly,Vol.35, No.20,pp.1735-1741.

[13]. Vaidyanathan. A,(1977), "Performance and Prospects of Crop Production in India"EconomicandPolitical Weekly, Vol.12, No.33/34, pp. 1355-1357+1359+1361+1363+1365+1367- 1368.

[14]. Vyas (1977), "Mainsprings ofAgricultural Growth In India" Journal ofIndian Society ofAgricultural Statistics, Vol.30,No.02,pp.01-18. 